\title{
A Complex Adaptive Systems (CAS) Approach to Measuring Organizational Adaptation in Organizations and Investigating its Relationship with R\&D Performance
}

\author{
Mahsa Fidanboy ${ }^{1}$ \\ Fidanboy Consulting, Cankaya, Ankara, Turkey
}

mahsa@fidanboyconsulting.com

Kerim Ozcan

Faculty of Business Administration, Ankara Yildirim Beyazit University, Esenboga Campus, Ankara, Turkey

Cemalettin Ocal Fidanboy ocal.fidanboy@ostimteknik.edu.tr Management Information Systems Department, OSTIM Technical University, Yenimahalle, Ankara, Turkey

\begin{abstract}
The aim of this paper is to develop a scale for measuring organizational adaptation and investigating its relationship with $R \& D$ performance. For this purpose, the items were developed in accordance with the dimensions of organization design, and the scale was tested first in a pilot study, and after making revisions and modifications, it was employed in the main study on two different samples, one for exploratory factor analysis (EFA), and the other for confirmatory factor analysis (CFA). The final scale consists of 17 items categorized under 4 dimensions labeled as contextual factors, tasks and roles, labor and labor division, and rules and regulations. The results indicate that except for rules and regulations, all dimensions of organizational adaptation bear higher values in high R\&D performance cluster. The organizations who enforce adaptation in all the other three dimensions yield more innovation which will help them in their decisions regarding their adaptive responses.
\end{abstract}

Keywords: organizational adaptation, complex adaptive systems perspective, R\&D performance

\section{Introduction}

Today, due to the more dynamic and turbulent environment which is much more demanding than before, the adaptability of the organizations and their people has attracted lots of attention. This adaptation can be viewed from different levels, and accordingly, with appropriate definitions. For instance, the macro level adaptation focuses on socio-economic adaptive responses of a system such as a society, while

\footnotetext{
${ }^{1}$ This research was part of the author's $\mathrm{PhD}$ thesis.
} 
the lowest level is the individual adaptation involving their schemata, the pattern and choice of their actions and behaviors. Despite being at different levels, all the levels are interdependent, and in line with the literature, it can be stated as nested [1]; the macro level is not apart from the individual level, but the accumulation, not necessarily the mathematic accumulation of course.

Adaptive capacity for socio-ecological systems was stated to bear the following components: the first is the capacity to deal with the contingencies in the environment, and the second is the capacity to improve its situation with respect to the environment(s) it is in exchange with [2]. There are few points which are noteworthy here. First of all, a CAS as a kind of open systems can exchange energy and/or information with not just one environment but several, or maybe these environments are nested which in this case the closest one might be called as the immediate environment. Secondly, in the absence of any changes, the system can still makes efforts to improve its situation in the environments, considering it from a CAS standpoint, the improvements occur till the system reaches another equilibrium in the form of a new pattern. This might origin from the activities of various agents found in the system itself, whose decisions and acts influence the decisions and acts of other agents. These improvements are similar to the concept of positive feedbacks in CAS where the signals direct the system towards the continuance of what it has been already doing or to maintain the situation it is currently found in.

Viewing the adaptation in relation with the learning casts light on two important facts associated with learning at individual and organizational levels: first is that what an individual learns in an organization and how he is going to use it for the future purposes is dependent on the position and function he was appointed at in the organization; second, the organizations may become less likely to take high impact risks as the times passes [3]. This highlights the importance of the adaptability of managers namely the managerial adaptability in order for an organization to reach its ideal adaptive capacity. Managerial adaptability was proposed as a multi-dimensional concept consisting of behavioral aspects, cognitive aspects, and socio-economic dimensions [4]. This gains significance whenever a change appears in the system whether it is infused by the environment, or it is originated from the organization, itself, and the response to this change is needed to be decided by the manager. Looking at this issue from a CAS viewpoint can relate the decision maker concept to the notion of agents in systems where an agent can decide on their activities interdependently with other agents, although they are independent, having freedom in the selection of their own actions, the consequences of their decisions change the contexts for the other agents, making them interdependent on each other.

Organizational adaptation was previously modeled in terms of where learning take place in an organization; in individuals, in the organizational structural or in both [3]. To clarify it, the organizational level is related to the organizational design where the organizations seek an optimal design for the environment they are located at [3]. Similarly, adaptability was suggested to rest in the relationship between the organization and its environment or to put it differently, the fit which is formed between the internal structure of the organization and the environment which is external to it [5]. Besides, ambidexterity does not only focus on the acceptance of 
different processes in an organization, but also subsumes contradictory structures and cultures [6], [7]. Given all mentioned, it can be concluded that the organizational adaptation is found in its design, or to say it in another way, this is the organizational design which undergoes changes in response to the external and/or internal changes.

Considering the scale developed for organizational innovation intensity [8] implies the two possible options facing the organizations regarding their approaches towards innovation, which was pointed at as the degree of innovation in the original article; one is radical which is reached when the organizational innovation intensity scores high [8], and the other is incremental. To move deeper into the descriptions of these two, in the radical approach, some new technologies or processes have come into existence, and in R\&D terminology, some kind of innovation has been occurred. Oppositely, the incremental approach touches on extracting the most from the available technologies or processes currently being employed. These are in the similar vein with the two aspects of organizational learning: exploitation and exploration [9], [10] which were used to explain the adaptive capacity of governance systems [11]. As presented in the literature, there should be a balance between exploration and exploitation activities in a system [11] or between its needs to innovate, and produce respectively [9], [12], [13]. This ability of a firm to concentrate on different degrees of innovation, from incremental to radical, "discontinuous" in that article, was named as organizational ambidexterity which was mentioned to be vital for the organization to survive for a long time [14], [7]. To clarify this, the activities at which the innovation in any of its forms take place can be deemed. Based on one of the categorizations found in the literature, innovation can be seen as managerial, process, marketing and product innovations [15]. The critical point here is that due to the vitality of the radical innovation for the survival of an organization, even a small amount of it in any of the aforementioned activities can make difference. To put it differently, for an organization to survive, radical innovation is expected to happen to any extent in any one of the activities. It might be the result behind the survival or even the great success many organizations achieve, those who have never released innovative products; indeed, their innovative marketing ideas have brought them those successes.

In this paper, first, a measure is developed for measuring organizational adaptation in accordance with organization design, and then, factor analyses are run to check the probable factorial structure of the scale, the number of sub-dimensions and the notions they are representative of. Subsequently, the R\&D performance in terms of innovation will be measured in the same organizations where the higher score of $\mathrm{R} \& \mathrm{D}$ performance represents more radical innovation than the incremental innovation, and vice versa. At the final stage, the scores for organizational adaptation on different dimensions are compared between low and high R\&D performance clusters to see whether high $\mathrm{R} \& \mathrm{D}$ performance is happening more in the adaptive organizations or not. 


\section{Methodology}

\subsection{Scale Items}

As stated earlier, the dimensions for organization design is used to develop a scale for organizational adaptation. There are two types of organizational dimensions: structural and contextual; structural dimension subsumes formalization, specialization, hierarchy of authority, centralization, professionalism, and personnel ratios; contextual dimension embraces size, organizational technology, goals and strategy, culture, and environment [16], however, environment is not included for the fact that the perspective employed in this study is CAS, viewing the organization as an open system in exchange with its environment, and therefore, taking the environment as a factor apart from the organization design.

\begin{tabular}{|c|c|}
\hline $\begin{array}{c}\text { Dimensions of an } \\
\text { Organization Design }\end{array}$ & Related Survey Items \\
\hline Formalization & $\begin{array}{l}\text { 1. Change in procedures, job descriptions, } \\
\text { regulations, and policy manuals } \\
\text { 2. Change in written rules } \\
\text { 3. Change in formal or informal rules }\end{array}$ \\
\hline Specialization & $\begin{array}{l}\text { 4. Change in the division of tasks into separate } \\
\text { jobs } \\
\text { 5. Change in the number of the tasks } \\
\text { 6. Change in the division of labor }\end{array}$ \\
\hline Hierarchy of Authority & $\begin{array}{l}\text { 7. Change in the hierarchy of authority } \\
\text { 8. Change of the immediate supervisor } \\
\text { 9. Change in the number of employees } \\
\text { reporting to a supervisor }\end{array}$ \\
\hline Centralization & 10. Change of the decision makers \\
\hline Professionalism & $\begin{array}{c}\text { 11. Change in the level of formal education of } \\
\text { the employees } \\
\text { 12. Change in the level of training of the } \\
\text { employees }\end{array}$ \\
\hline Personnel Ratios & $\begin{array}{l}\text { 13. Change of the personnel at different } \\
\text { departments } \\
\text { 14. Change of the personnel at different tasks } \\
\text { (functions) }\end{array}$ \\
\hline Size & 15. Change in the number of employees \\
\hline Organizational Technology & $\begin{array}{l}\text { 16. Change in the tools used for producing } \\
\text { products and/or services } \\
\text { 17. Change in the techniques used for } \\
\text { producing products and/or services } \\
\text { 18. Change in the actions used for producing } \\
\text { products and/or services }\end{array}$ \\
\hline
\end{tabular}




\begin{tabular}{|c|c|}
\hline Goals and Strategy & $\begin{array}{c}\text { 19. Change of the purpose of an organization } \\
\text { 20. Change in the competitive techniques of an } \\
\text { organization }\end{array}$ \\
\hline Culture & $\begin{array}{c}\text { 21. Change in the values of an organization } \\
\text { 22. Change in the understandings and norms } \\
\text { shared by the employees }\end{array}$ \\
\hline
\end{tabular}

Table 1. Items for the scale of organizational adaptation

\subsection{Data Collection}

The questionnaires were distributed among R\&D experts and managers of the firms located at four of the technoparks in Ankara, Turkey. The sampling method was snowball sampling; the first respondents were the ones with previous acquaintance who then provided referrals to the rest of the participants. Two different samples of 150 were used in the pilot study, and also at the first step of the main study as it is the recommended minimum sample size for the conduction of EFA [17]. CFA in the main study was conducted on a sample of 233, taking 200 as the suggested minimum sample size for performing CFA [18], [17]. The last analysis of the main study, cluster analysis, was conducted on 81 organizations of the same technoparks.

\section{Results}

\subsection{Pilot Study}

This scale was developed for the first time and a high value of the Cronbach's alpha (0.919) was obtained. The Bartlett's test was significant (sig. $<0.05)$, and five factors were extracted explaining $68.115 \%$ of the variance. . The factor loadings for all the factors exceed the significant level which is 0.450 for the sample size of 150 [19]. Items 5 and 12 will be excluded from the main study because of the crossloadings. Item 8 is loaded by the first factor which mainly consists of the items related to context, hence, this item will not be also included in the next analysis. The items loaded by the second factor are all associated with labor and labor division except item 16 which will be taken out from the further analysis. In Table 3, the items are represented along with the factors they are loaded by, and the factors were labeled taking their contents into consideration. In addition, Cronbach's alpha scores were depicted in the same table for each of the dimensions, all above 0.70 which indicate high level of internal consistency [20].

\begin{tabular}{|c|c|c|c|c|c|}
\hline Items & \multicolumn{5}{|c|}{ Component } \\
\hline & 1 & 2 & 3 & 4 & 5 \\
\hline $\begin{array}{c}\text { 1. Change in procedures, job descriptions, } \\
\text { regulations, and policy manuals }\end{array}$ & -.041 & -.095 & .109 & $\mathbf{. 8 9 6}$ & .132 \\
\hline 2. Change in written rules & .086 & .072 & .032 & $\mathbf{. 8 0 7}$ & -.017 \\
\hline 3. Change in formal or informal rules & -.207 & .011 & .070 & $\mathbf{. 8 4 4}$ & .325 \\
\hline
\end{tabular}




\begin{tabular}{|c|c|c|c|c|c|}
\hline $\begin{array}{l}\text { 4. Change in the division of tasks into separate } \\
\text { jobs }\end{array}$ & .026 & .114 & .492 & .357 & -.317 \\
\hline 5. Change in the number of the tasks & 203 & .493 & .476 & .021 & .079 \\
\hline 6. Change in the div & -.030 & .303 & .720 & -.030 & .063 \\
\hline 7. Change in the hierarchy of authority & .136 & -.113 & .769 & .156 & -.109 \\
\hline 8. Change of the immediate supervisor & .663 & .073 & .434 & -.158 & -.161 \\
\hline $\begin{array}{l}\text { 9. Change in the number of employees } \\
\text { reporting to a supervisor }\end{array}$ & .027 & .574 & .436 & -.220 & .151 \\
\hline 10. Change of the & .309 & -.069 & .465 & .225 & .036 \\
\hline $\begin{array}{r}\text { 11. Change in the lev } \\
\text { the e }\end{array}$ & .221 & .022 & -.016 & .242 & .771 \\
\hline $\begin{array}{l}\text { 12. Change in the } \\
\text { en }\end{array}$ & .014 & .554 & -.165 & .090 & .582 \\
\hline $\begin{array}{r}\text { 13. Change of the } \\
\text { dep }\end{array}$ & -.078 & .880 & .083 & -.042 & -.060 \\
\hline 14. Change of the $\mathrm{p}$ & -.117 & .784 & .181 & .043 & .073 \\
\hline 15. Change in the nu & .079 & 3 & .145 & 39 & .153 \\
\hline $\begin{array}{l}\text { 16. Change in the tools } \\
\text { products and/c }\end{array}$ & .393 & .521 & -.211 & .145 & .013 \\
\hline $\begin{array}{l}\text { 17. Change i } \\
\text { producing } \mathrm{p}\end{array}$ & .538 & .434 & -.165 & .064 & -.073 \\
\hline $\begin{array}{l}\text { 18. Change in the action } \\
\text { products and/ }\end{array}$ & .626 & .354 & -.208 & .130 & -.155 \\
\hline 19. Change of & .796 & .009 & .082 & .068 & -.060 \\
\hline $\begin{array}{r}\text { 20. Change in the co } \\
\text { org }\end{array}$ & .776 & -.009 & .025 & -.263 & .341 \\
\hline 21. Change in the values of an organization & .828 & -.160 & .028 & .009 & .291 \\
\hline $\begin{array}{l}\text { 22. Change in the understandings and norms } \\
\text { shared by the employees }\end{array}$ & .823 & -.2 & 136 & .096 & .178 \\
\hline
\end{tabular}

Table 2. Pattern matrix for the pilot study

\begin{tabular}{|c|c|}
\hline Items & $\begin{array}{c}\text { Factor Number } \\
\text { /Dimensions/ Reliability } \\
\text { (Cronbach's Alpha) }\end{array}$ \\
\hline $\begin{array}{l}\text { 1. Change in procedures, job descriptions, } \\
\text { regulations, and policy manuals }\end{array}$ & \multirow[t]{3}{*}{$\begin{array}{l}\text { 4. Rules and regulations } \\
\qquad(0.866)\end{array}$} \\
\hline 2. Change in written rules & \\
\hline 3. Change in formal or informal rules & \\
\hline $\begin{array}{l}\text { 4. Change in the division of tasks into separate } \\
\text { jobs }\end{array}$ & 3. Tasks and roles $(0.763)$ \\
\hline 5. Change in the number of the tasks & $\begin{array}{l}\text { Excluded from the main } \\
\text { study }\end{array}$ \\
\hline 6. Change in the division of labor & 3. Tasks and roles \\
\hline
\end{tabular}




\begin{tabular}{|c|c|}
\hline 7. Change in the hierarchy of authority & 3. Tasks and roles \\
\hline 8. Change of the immediate supervisor & $\begin{array}{l}\text { Excluded from the main } \\
\text { study }\end{array}$ \\
\hline $\begin{array}{l}\text { 9. Change in the number of employees reporting } \\
\text { to a supervisor }\end{array}$ & 2. Labor and labor division \\
\hline 10. Change of the decision makers & 3. Tasks and roles \\
\hline $\begin{array}{l}\begin{array}{l}\text { 11. Change in the level of formal education of the } \\
\text { employees }\end{array}\end{array}$ & 5. Professionalism \\
\hline $\begin{array}{l}\text { 12. Change in the level of training of the } \\
\text { employees }\end{array}$ & $\begin{array}{l}\text { Excluded from the main } \\
\text { study }\end{array}$ \\
\hline $\begin{array}{l}\text { 13. Change of the personnel at different } \\
\text { departments }\end{array}$ & \multirow[t]{3}{*}{$\begin{array}{l}\text { 2. Labor and labor division } \\
\qquad(0.829)\end{array}$} \\
\hline $\begin{array}{l}\text { 14. Change of the personnel at different tasks } \\
\text { (functions) }\end{array}$ & \\
\hline 15. Change in the number of employees & \\
\hline $\begin{array}{l}\text { 16. Change in the tools used for producing } \\
\text { products and/or services }\end{array}$ & $\begin{array}{l}\text { Excluded from the main } \\
\text { study }\end{array}$ \\
\hline $\begin{array}{l}\text { 17. Change in the techniques used for producing } \\
\text { products and/or services }\end{array}$ & \multirow[t]{6}{*}{ 1. Contextual Factors $(0.865)$} \\
\hline $\begin{array}{l}\text { 18. Change in the actions used for producing } \\
\text { products and/or services }\end{array}$ & \\
\hline 19. Change of the purpose of an organization & \\
\hline $\begin{array}{l}\text { 20. Change in the competitive techniques of an } \\
\text { organization }\end{array}$ & \\
\hline 21. Change in the values of an organization & \\
\hline $\begin{array}{l}\text { 22. Change in the understandings and norms } \\
\text { shared by the employees }\end{array}$ & \\
\hline
\end{tabular}

Table 3. Dimensions of organizational adaptation- Pilot study

\subsection{Main Study}

4 items were omitted after the pilot study, and the main study was done with 18 items. Promax rotation, as a type of oblique rotation, was preferred for the reason that there might be correlations between the factors. Taking a look at Table 4, it can be seen that item 7 is loaded by two factors, raising a cross-loading problem, therefore, it will not be placed in the model. Subsequently, multi-normality test as an assumption for CFA was run, and after diagnosing the non-normality problem of the data, robust maximum likelihood (ML) estimation was used and the results are illustrated in Table 5. To conclude, an 18-item scale was tested, and four dimensions were found labeled as contextual factors, tasks and roles, labor and labor division, and rules and regulations respectively. Besides, Cronbach's alpha was calculated separately for each of the dimensions along with the scale as a whole. Cronbach's alpha for the whole scale was measured as 0.880 . Similarly, for the first factor was $0.857,0.800$ for the second factor, and 0.765 and 0.850 for the third, and forth factors respectively. 
R\&D performance was measured using previously developed organizational innovation intensity scale [8], though the items representing managerial innovation were not included in this study since they might have interfered with the items seeking information on managerial issues in the organizational adaptation scale. After running both EFA and CFA analyses, a two-factor model was resulted of which the items loaded by the first factor asked the respondents about the extent to which innovation occurs in their companies whereas the the second group of items investigates the forms of innovation whether radical or incremental. Similar to the process taken for organizational adaptation scale, before CFA, multi-normality test was conducted, and the data were found to be non-normal. As a result, the robust ML estimation was used and the data are presented in Table 6.

In the last analysis of this research, cluster analysis was performed on 81 organizations based on their scores on their R\&D performance. Two clusters were formed, one including 14, and the other consisting of 67 companies. The large cluster bears low score on R\&D performance while the small cluster scored high on both factors of the organizational innovation intensity.

\begin{tabular}{|c|c|c|c|c|}
\hline \multirow[t]{2}{*}{ Items } & \multicolumn{4}{|c|}{ Component } \\
\hline & 1 & 2 & 3 & 4 \\
\hline 17. Change in the values of an organization & .789 & .025 & -.103 & .083 \\
\hline $\begin{array}{l}\text { 13. Change in the techniques used for producing } \\
\text { products and/or services }\end{array}$ & .772 & -.021 & -.012 & -.013 \\
\hline $\begin{array}{l}\text { 18. Change in the understandings and norms } \\
\text { shared by the employees }\end{array}$ & .759 & .259 & -.164 & -.017 \\
\hline 15. Change of the purpose of an organization & .755 & -.044 & .133 & -.091 \\
\hline $\begin{array}{c}\text { 16. Change in the competitive techniques of an } \\
\text { organization }\end{array}$ & .738 & -.094 & .007 & .085 \\
\hline $\begin{array}{l}\text { 14. Change in the actions used for producing } \\
\text { products and/or services }\end{array}$ & .738 & -.131 & .098 & .096 \\
\hline 5. Change in the division of labor & -.054 & .886 & -.121 & .065 \\
\hline 6. Change in the hierarchy of authority & .045 & .797 & -.113 & .132 \\
\hline $\begin{array}{l}\text { 4. Change in the division of tasks into separate } \\
\text { jobs }\end{array}$ & -.183 & .690 & .040 & .292 \\
\hline 8. Change of the decision makers & .141 & .622 & .212 & -.168 \\
\hline $\begin{array}{l}\text { 7. Change in the number of employees reporting } \\
\text { to a supervisor }\end{array}$ & -.008 & .476 & .470 & -.169 \\
\hline $\begin{array}{l}\text { 10. Change of the personnel at different } \\
\text { departments }\end{array}$ & .035 & -.081 & .853 & .083 \\
\hline $\begin{array}{l}11 \text { Change of the personnel at different tasks } \\
\text { (functions) }\end{array}$ & -.014 & .142 & .811 & .014 \\
\hline
\end{tabular}




\begin{tabular}{|c|c|c|c|c|}
\hline $\begin{array}{c}\text { 9. Change in the level of formal education of the } \\
\text { employees }\end{array}$ & -.081 & -.153 & $\mathbf{. 6 5 5}$ & .252 \\
\hline $\begin{array}{c}\text { 12. Change in the number of employees } \\
\begin{array}{c}\text { 1. Change in procedures, job descriptions, } \\
\text { regulations, and policy manuals }\end{array}\end{array}$ & -.045 & .377 & $\mathbf{. 4 7 9}$ & -.150 \\
\hline 2. Change in written rules & .113 & .144 & .000 & $\mathbf{. 8 5 8}$ \\
\hline 3. Change in formal or informal rules & .062 & -.097 & -.034 & $\mathbf{. 8 0 9}$ \\
\hline
\end{tabular}

Table 4. Pattern matrix for the main study

\begin{tabular}{|c|c|c|c|c|c|c|c|c|}
\hline Model & $\mathbf{n}$ & $\boldsymbol{\chi}^{\mathbf{2}}$ & $\mathbf{d f}$ & $\boldsymbol{\chi}^{\mathbf{2}} / \mathbf{d f}$ & CFI & AGFI & NFI & RMSEA \\
\hline $\begin{array}{c}\text { Four- factor } \\
\text { (Robust ML) }\end{array}$ & 233 & 243.690 & 109 & 2.235 & 0.840 & - & - & 0.073 \\
\hline
\end{tabular}

Table 5. Goodness- of- fit-indices for CFA for organizational adaptation scale

\begin{tabular}{|c|c|c|c|c|c|c|c|c|}
\hline Model & $\mathbf{n}$ & $\boldsymbol{\chi}^{\mathbf{2}}$ & $\mathbf{d f}$ & $\boldsymbol{\chi}^{\mathbf{2}} / \mathbf{d f}$ & CFI & AGFI & NFI & RMSEA \\
\hline $\begin{array}{c}\text { Two-factor } \\
\text { (Robust ML) }\end{array}$ & 233 & 13.241 & 6 & 2.20 & 0.974 & - & - & 0.072 \\
\hline
\end{tabular}

Table 6. Goodness- of- fit-indices for CFA for organizational innovation intensity scale

Table 7 contains the means for each of the dimensions of organizational adaptation in clusters with low and high R\&D performance.

\begin{tabular}{|c|c|c|}
\hline Dimensions & Low Performer & High Performer \\
\hline Contextual factors & 24.84 & 25.16 \\
\hline Tasks and roles & 21.06 & 21.53 \\
\hline Labor and labor division & 19.23 & 19.54 \\
\hline Rules and regulations & 15.03 & 14.86 \\
\hline
\end{tabular}

Table 7. Scores on different dimensions of organizational adaptation in the two clusters

\section{Discussion}

In order for an organization to respond to changes either external or internal, changes needed to be made to the dimension or dimensions of the organization design. Different dimensions of the organization design were investigated to see whether they are scored differently in organizations with low and high R\&D performance. High performers reflect their adaptive responses in the contextual factors, tasks and roles, and labor and labor division. In contrary, the results suggest that changes in rules and regulations are not approached by high performers. Since adaptation is desired from a firm for its long term survival and success which is consistent with CAS perspective, the different result for this dimension needed to be illuminated. This can be due to the bias employees have towards the rules and regulation. The employees might be dissatisfied with any kinds of changes in rules and regulation probably because they 
perceive it as something against them, or to put in other words, the changes are perceived to not to be in their favor even if they might not be so. The roots can be traced back to the recruitment process of the companies, and when the employees accept the rules and regulations as they were at that time, reluctant to having them modified and altered. That is why high performers select not to take this risk and continue with their old rules and regulations.

\section{Conclusion}

In this paper, a multi-dimensional scale was developed for organizational adaptation subsuming contextual factors, tasks and roles, labor and labor division, and rules and regulation dimensions. EFA and CFA analyses were performed on two different samples and the fit of the model with the data was controlled. The scores of each of the dimensions were calculated in the companies categorized after the cluster analysis under two clusters of low and high R\&D performance. The companies with high R\&D scores were found to adapt in any dimensions except rules and regulations. As for rules and regulations, they go under changes more in low performers than the high performers that might be due to the employees' bias towards the changes to them.

The future research can be directed towards the investigation of the relationship between the employees' adaptation as individuals, and organizational adaptation. It will be a multi-level study with nested levels, and will shed light on how the same concepts at individual and organizational levels vary quantitatively. In this manner, there will be a chance to find the factors which play role in the variance between the individual and organizational adaptation, or to be clearer, the factors who lead to changes in the adaptation of an employee as an individual apart from the organization and him/her when working within the organization. Furthermore, the relationship of the organizational adaptation with the other organizational concepts can also be researched in a quantitative way.

\section{References}

[1] J. W. Begun, B. Zimmerman and K. Dooley, "Health Care Organizations as Complex Adaptive Systems," in Advances in Health Care Organization Theory, S. M. Mick and M. Wyttenbach, Eds., San Francisco, JosseyBass, 2003, pp. 253-288.

[2] G. C. Gallopin, "Linkages between Vulnerability, Resilience, and Adaptive Capacity," Global Environmental Change, p. 293-303, 2006.

[3] K. M. Carley and D. M. Svoboda, "Modeling Organizational Adaptation as a Simulated Annealing Process," Sociological Methods \& Research, pp. 138-168, 1996.

[4] A. Karaevli and D. T. T. Hall, "How Career Variety Promotes the Adaptability of Managers: A Theoretical Model," Journal of Vocational Behavior, p. 359-373, 2006. 
[5] M. R. T. Koller, "Exploring Adaptability in Organizations: Where Adaptive Advantage Comes from and What it is Based upon," Journal of Organizational Change, pp. 837-854, 2016.

[6] R. J. Seidle, "Sequences of Learning Types for Organizational Ambidexterity," The Learning Organization, pp. 381-396, 2019.

[7] M. L. Tushman and C. A. O'Reilly III, "Ambidextrous Organization: Managing Evolutionary and Revolutionary Change," California Management Review, pp. 1-23, 1996.

[8] J. Weerawardena, "The Role of Marketing Capability in Innovation-based Competitive Strategy," Journal of Strategic Marketing, vol. 11, no. 1, pp. 15-35, 2003.

[9] M. Uhl-Biena and M. Arena, "Leadership for Organizational Adaptability: A Theoretical Synthesis and Integrative Framework," The Leadership Quarterly, p. 89-104, 2018.

[10] J. G. March, "Exploration and Exploitation in Organizational Learning," Organization Science, pp. 71-87, 1991.

[11] A. Duit and V. Galaz, "Governance and Complexity_Emerging Issues for Governance Theory," Governance: An International Journal of Policy, Administration, and Institutions, pp. 311-335, 2008.

[12] R. Duncan, "The Ambidextrous Organization: Designing Dual Structures for Innovation," in The Management of Organization Design: Strategies and Implementation, New York, North Holland, 1976, p. 167-188.

[13] C. A. O'Reilly III and M. L. Tushman, "The Ambidextrous Organization," Harvard Business Review, p. 74-81, 2004.

[14] C. A. O’Reilly III and M. L. Tushman, "Organizational Ambidexterity," 11 May 2013. [Online]. Available: https://www.hbs.edu.

[15] A. O’Cass and J. Weerawardena, "Examining the Role of International Entrepreneurship, Innovation and International Market Performance in SME Internationalisation," European Journal of Marketing, vol. 43, no. 11/12, pp. 1325-1348, 2009.

[16] R. L. Daft, Organization Theory and Design, 9th ed., OH: Thomson Higher Education, 2007.

[17] T. R. Hinkin, "A Review of Scale Development Practices in the Study of Organizations," Journal of Management, pp. 967-988, 1995.

[18] J. W. Hoelter, "The Analysis of Covariance Structures: Goodness-of-fit Indices," Sociological Methods and Research, pp. 325-344, 1983.

[19] J. Hair Jr, W. C. Black, B. J. Babin and R. E. Anderson, Multivariate Data Analysis, Essex, UK: Pearson Limited Education, 2009. 
[20] L. Bartlett, "Methods," in Pilot Test for Reliability and Validity of a New Assessment Tool Measuring Relationships between Individual Health and Environmental Sustainability, Halifax, Nova Scotia, Dalhousie University, 2013, pp. 14-16. 